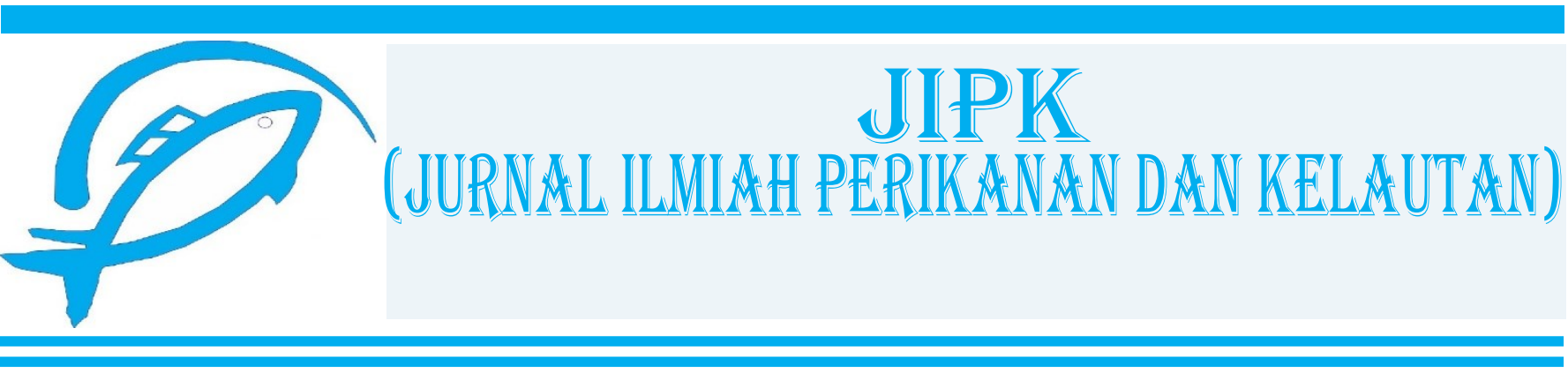

Research Article

\title{
Toxicity and histopathological effects of toxic dinoflagellate, Alexandrium catenella exudates on larvae of blue mussel, Mytilus galloprovincialis, and Pacific oyster, Crassostrea gigas
}

\author{
Supono Supono ${ }^{1,2 *}$ (D), Graeme Knowles ${ }^{3}$, and Christopher Bolch ${ }^{4}$
}

${ }^{1}$ Institute of Marine Science, University of Auckland, P.O. Box 349, Warkworth 0941, New Zealand

${ }^{2}$ Loka Konservasi Biota Laut Bitung, Research Center for Oceanography, Indonesian Institute of Sciences, Sulawesi Utara 95527

${ }_{3}$ Animal Health Laboratory, Department of Primary Industries, Parks, Waters and Environment, P.O. Box 46, Kings Meadows

Tasmania, 7249, Australia

${ }^{4}$ Institute for Marine and Antarctic Studies, University of Tasmania, Locked Bag 1370, Launceston, Tasmania, 7250 , Australia.

\section{OPEN \\ (2) \\ ACCESS}

\section{ARTICLE INFO}

Received: April 25, 2020

Accepted: July 05, 2020

Published: September 28, 2020

*) Corresponding author:

E-mail:supono@lipi.go.id

Keywords:

Algal Bloom

Hatchery

Shellfish

Filtration

Histology

This is an open access article under the CC BY-NC-ND license (http://creativecommons.org/licenses/by-nc-nd/4.0/)

\begin{abstract}
Blooms of the toxic dinoflagellate Alexandrium catenella have affected shellfish industries globally due to their capacity to produce paralytic shellfish toxins (PST). This study aimed to investigate the toxicity effect of exudate $A$. catenella on larvae of blue mussel Mytilus galloprovincialis and Pacific oyster Crassostrea gigas and filtration methods to reduce the toxic effect. Blue mussel and Pacific oyster larvae were assessed their survival and histopathological changes after exposure to

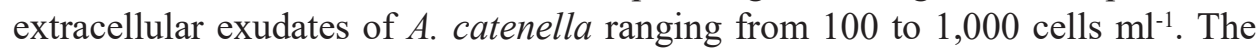
results showed that exposure to exudate $A$. catenella caused significantly higher larval mortality (39 to 52\%) than exposure to an equivalent biovolume of the nontoxic species, Tisochrysis lutea (33\%) or unfed controls (17\%). Filter-sterilization $(0.22 \mu \mathrm{m})$ of exudates and activated carbon filtration decreased the mortality of Pacific oyster larvae to a level similar to controls (unfed), with the exception of the highest concentrations ( 600 and 1,000 cells ml$^{-1}$ ) and mortality of bluemussel larvae mortality by $32 \%$ respectively. Blue mussel larvae exposed to exudate $A$. catenella showed pathological changes mainly in the stomach (digestive gland and style sac) as early as three hours after onset of exposure. The findings of this study suggest that early detection of blooms in the vicinity of mussel and Pacific oyster hatcheries and taking steps to mitigate their effects, is important to reduce the effects of $A$. catenella blooms on shellfish larval rearing.
\end{abstract}

Cite this as: Supono, S., Knowles, G., \& Bolch, C. (2020). Toxicity and histopathological effects of toxic dinoflagellate, Alexandrium catenella exudates on larvae of blue mussel, Mytilus galloprovincialis, and Pacific oyster, Crassostrea gigas. Jurnal Ilmiah Perikanan dan Kelautan, 12(2):188-198. http://doi.org/10.20473/jipk.v12i2.22363 


\section{Introduction}

The species diversity, geographical distribution and associated impacts of harmful algal blooms (HAB) have globally increased, spanning from the Northern to the Southern hemisphere. The number of toxic species, bloom occurrence and economically affected sectors have increased significantly over the last several decades (Anderson et al., 2010; Hoagland et al., 2002). The annual economic losses inflicted by blooms has been estimated at reaching USD 43 million in the United State of America (USA), USD 850 million in Europe and USD 1 billion in Asia, representing four main sectors; public health, commercial fisheries, recreation or tourism and monitoring/management (Anderson et al., 2000; Trainer and Yoshida, 2014).

Among groups causing HABs, dinoflagellates (Dinophyceae) are considered to be the most widespread and frequently recorded (Cembella and John, 2006; Hallegraeff, 2014). Species of the genus Alexan-drium are the most widespread, common HAB genera with approximately one third of more than 30 species known to produce paralytic shellfish toxins (PST) that accumulate through vertical transmission in the food chains (Anderson et al., 2012; Samson et al., 2008). Some species, including the widespread cold-temperate species Alexandrium catenella produce both PSTs and other poorly characterized extracellular toxic or allelopathic compounds that have harmful effects on marine fauna and flora (John et al., 2014; Tillman and Hansen, 2009; Tillman et al., 2007) including shellfish (Bricelj and Shumway, 2011; Núñez Vázquez et al., 2011).

Alexandrium catenella is one of the Alexandrium tamarense species complex group demonstrating sxtA4 (the gene responsible for producing saxitoxin) and paralytic shellfish poisoning (PSP) toxicity (John et al., 2014), and is capable of producing extracellular compounds (Tillman and Hansen, 2009). A wide range of species of marine organisms has been reported to be adversely affected by Alexandrium including shellfish (Bricelj et al., 2011; Haberkorn et al., 2010; NúñezVázquez et al., 2011; Pate, 2007). The susceptibility of adult shellfish to toxic Alexandrium is dependent upon a number of factors, including developmental stage (Yan et al., 2003; Yan et al., 2001; Mu and Li, 2013), chemical structure and action mode of toxins (Bricelj et al., 1991; Hégaret et al., 2007), duration exposure (Contreras et al., 2012) and species (Hégaret et al., 2007). Mussels are considered to be less sensitive to the effects of saxitoxin (a PST produced by Alexandrium) and to accumulate toxin more rapidly (Bricelj et al., 1990), but little is known of the susceptibility of either adults or larvae to other extra-cellular compounds produced by A. catenella.

Over the period from 2012 to 2016, intense winter spring blooms of A. catenella affected much of the eastern coast of Tasmania, causing regular and prolonged harvest closures of, clams, scallop abalone, and rock lobster fisheries and farmed oysters and mussels (Bolch et al., 2014; Hallegraeff et al., 2017). Particu- larly intense blooms (up to 300,000 cells $\mathrm{L}^{-1}$ ) during spring 2015 and 2016 were also associated with high mortality of adult farmed oysters, and a series of shell- fish hatchery production failure of both mussels and oyster larvae (Hallegraeff et al., 2017). Most previous research has focused on the effects of live cells on shell- fish (Mu and Li, 2013; Yan et al., 2001; Yan et al., 2003) however, water intake and treatment systems of marine hatcheries routinely exclude algal cells/biomass using a combination of filtration to (effective to $<1 \mu \mathrm{m}$ diameter) followed by UVtreatment to reduce bacterial loads. Dissolved organic carbon (DOC) and potentially toxic extracellular compounds exuded by $A$. catenella blooms (exudates) can pass through the water treatment systems largely intact, entering the larval rearing systems and may directly or indirectly cause mortality of shellfish larvae. This study aims to investigate the lethal concen- tration, and histopathological effects of $A$. catenella ex- udates on shellfish larvae, particularly blue mussels and oysters.

\section{Materials and Methods}

\subsection{Materials}

Materials used in this study included 6 days postfertilization (dpf) larvae of blue mussels (Mytilus galloprovincialis) and Pacific oysters (Crassostrea gigas) at $\sim 138 \mu \mathrm{m}$ shell length, culture of Tisochry sis lutea and Alexandrium catenella, K-medium, 10\% buffered seawater-formalin, alcohol $70 \%$, Oxoid no.3 agar media, $0.22 \mu \mathrm{m}$ Isopore (Millipore, USA), Sedgewick-Rafter and Haemocytometer counting chamber (Thermo Fisher Scientific, USA) and $50 \mathrm{ml}$ plasticjars.

\subsection{Methods}

Shellfish larvae, blue mussels (Mytilus galloprovincialis) and Pacific oysters (Crassostrea gigas) were obtained from Spring Bay Seafood Pty Ltd, Tasmania, Australia. Larvae were kept in $0.2 \mu \mathrm{m}$ filtered seawater at $20{ }^{\circ} \mathrm{C}$ under light intensity of $30 \mu \mathrm{mol} \mathrm{m}^{-2} \mathrm{~s}$ ${ }^{1}$ in IMAS aquaculture center, University of Tasmania, Australia. A Saxitoxin producing species, Alexandrium catenella, was used for treatment and the non-toxic algae Tisochrysis lutea was used as control. All algae were grown in $250 \mathrm{ml}$ flasks to late log phase (12 to 14 days) in $\mathrm{K}$ medium prepared using filter-sterilized sea water $(0.22 \mu \mathrm{m}$ Isopore, Millipore, USA $)$ at $18{ }^{\circ} \mathrm{C}$ and $60 \mu \mathrm{mol} \mathrm{m}{ }^{-2} \mathrm{~s}^{-1}$ of light intensity. Culture density was estimated by triplicate cell counts using a Sedgewick- 
Rafter and Haemocytometer counting chamber. Next, harvested cultures were transferred to $50 \mathrm{ml}$ tubes and subjected to 10 minutes of $4,000 \mathrm{rpm}$ centrifugation. Culture supernatants (exudates) were then removed, examined under a compound microscope to ensure the absence of algal cell materials, and frozen at $-20^{\circ} \mathrm{C}$ prior to use.

\subsubsection{Acute toxicity of exudates A. catenella on blue mussel larvae}

An acute toxicity test was carried out in triplicate by exposing 6 days post fertilization (dpf) blue mussel larvae (10 larvae $\left.\mathrm{ml}^{-1}\right)$ to exudates of $A$. catenella at equivalent concentrations of $100,300,600$ and 1,000 cells $\mathrm{ml}^{-1}$. The larvae in control group were divided into two groups; control 1-unfed (no materials added) and control 2-exposed to exudate $T$. lutea at standard hatchery food concentration $\left(30,000\right.$ cells $\left.\mathrm{ml}^{-1}\right)$. After 48 hours of exposure, the larvae in each group were removed and transferred to new $0.2 \mu \mathrm{m}$ filtered seawater for mortality assessment. Larval mortality was assessed following criteria of Jacobson et al. (1993).

\subsubsection{Effects of $0.22 \mu \mathrm{m}$ and activated carbon filtration on the toxicity of exudates $A$. catenella}

Due to unavailability of blue mussel larvae after broodstock spawning (May-June), the second acute toxicity, to investigate the potential role of algal exudates-associated bacteria on larval mortality, was carried out on oyster larvae. Larvae in treatment and control were divided into two groups; the first group was exposed to $0.22 \mu \mathrm{m}$ filter-sterilized exudates and a second group was exposed to unfiltered exudates at equivalent concentration of 100,300,600 and 1,000 cells $\mathrm{ml}^{-1}$ of $A$. catenella (treatment) and $T$. lutea (control). The concentration of T. lutea was adjusted based on its bio-volume which is approximately 100 times less than A. catenella (Munir et al., 2015; Olenina et al., 2006). Larval mortality was assessed after $48 \mathrm{~h}$.

To identify the effect of activated carbon filtration, two groups of blue mussel larvae were exposed to exudates of $A$. catenella at an equivalent concentration of 1,500 cells ml $^{-1}$. Larvae from the first group (control) were exposed to $0.22 \mu \mathrm{m}$ filter-sterilized without pass- ing through activated carbon and larvae from the second group were exposed to $0.22 \mu \mathrm{m}$ filtersterilized filtered through activated carbon. Larval mortality was then assessed following 48 hours exposure.

\subsubsection{Histopathological findings related to exudates from A. catenella on blue mussel larvae}

Toinvestigate the histopathological findings related to $A$. catenella, 3 dpf blue mussel larvae at density of 10 larvae $\mathrm{ml}^{-1}$ were exposed to 1,500 cells $\mathrm{ml}^{-}$exudates. Larvae were removed at every 3, 15, 24 and 48 hours exposure, fixed in $10 \%$ buffered seawater-formalin and processed for histological examination using double embedding techniques (Feist and Bucke,1983). The prevalence and intensity of histopathological findings were measured following Basti et al. (2016) with modification. Each pathological finding was recorded as either absent (0) or present (1) and the intensity was scored as the percentage of the affected areas; 0 to $25 \%$ (mild), 26 to $80 \%$ (moderate) and $>80 \%$ (heavy). The average prevalence was interpreted as low ( 0 to 0.4$)$, intermediate $(0.41$ to 0.8$)$ and high $(0.81$ to 1$)$. The average intensity was interpreted as mild (0 to 1), moderate (1.01 to 1.90$)$ or heavy (1.91 to 3 ).

\subsection{Data Analysis}

All data analysis was performed using GraphPad Prism version 7.0 for Mac (GraphPad Software, La Jolla California, USA). Normality (Shapiro-Wilk test) was checked a priori by column statistic. One-way and twoway ANOVA was conducted to compare the effects of exudates treatment, effects of $0.22 \mu \mathrm{m}$ filtration on the toxicity of $A$. catenella on larval mortality and mean prevalence and intensity of each pathological change over exposure duration. A Tukey's post hoc test was applied at the significance level of 0.05 .

\section{Results and Discussion}

\subsection{Acute toxicity of exudates A. catenella on blue mussel larvae}

Mortality of mussel larvae exposed to unfiltered exudates of $A$. catenella and $T$. lutea was higher than the mortality of unfed larvae. The highest mortality was observed after exposure to $A$. catenella exudate equivalent to 600 cells ml $^{-1}$, whereas the remaining concentrations showed similar mortality to larvae exposed to non-toxic T. lutea exudates (Figure 1). Larvae, which died, following exposure to exudate $A$. catenella showed the absence of internal organ (transparent), fusion of velum cilia and biofilm engulfing bacteria.

Microalgal exudates of dinoflagellates are known to have a number of effects on larval bivalves including feeding inhibition, morphological abnormalities, and decreasing hatching rates (Thompson et al., 1994). Saxitoxins have also been shown to have direct effects on shellfish physiology, metabolism and gene expression (Detree et al., 2016). Tasmanian strains of $A$. catenella produce a range of PSTs including sulfocarbamoyl derivatives $\mathrm{C} 1$ and C2, gonyautoxins (GTX1-4), decarbamoyl derivatives and saxitoxin (Bolch et al.,2014). 


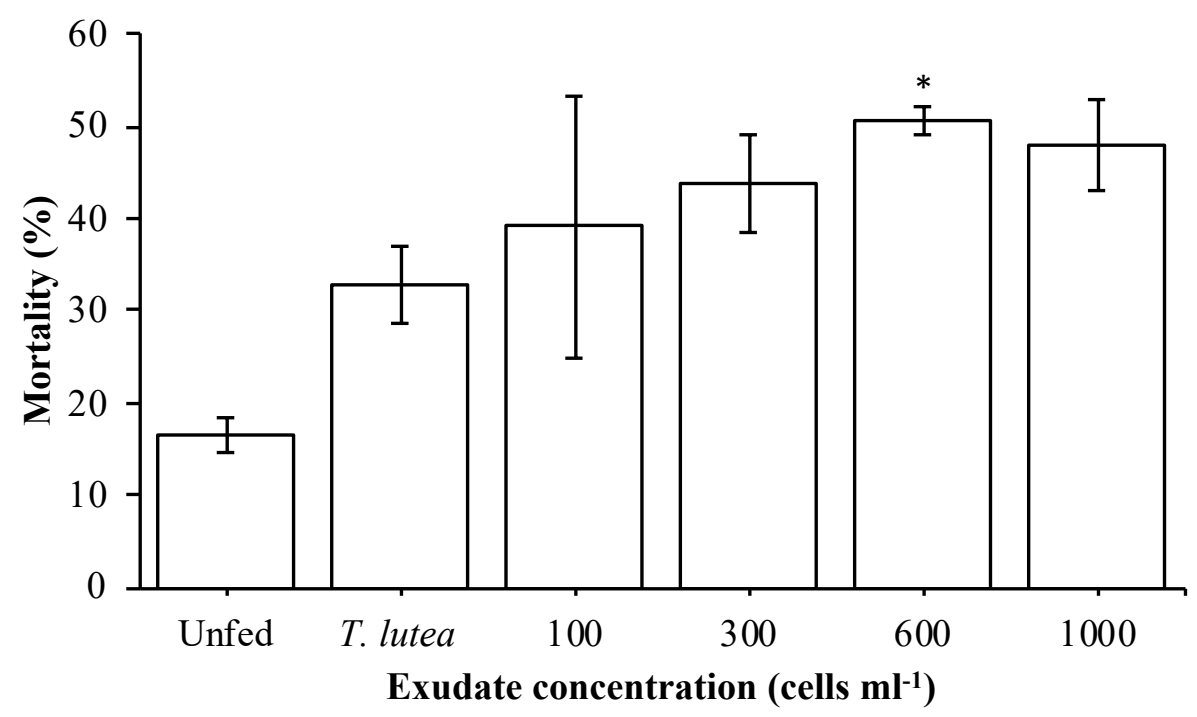

Figure 1. Mean ( $\pm \mathrm{SE}, \mathrm{n}=3$ ) mortality of blue mussel larvae exposed to different exudate concentration of $A$. catenella. $(*)$ indicates significant difference from control (unfed) ( $\mathrm{n}=3)$.

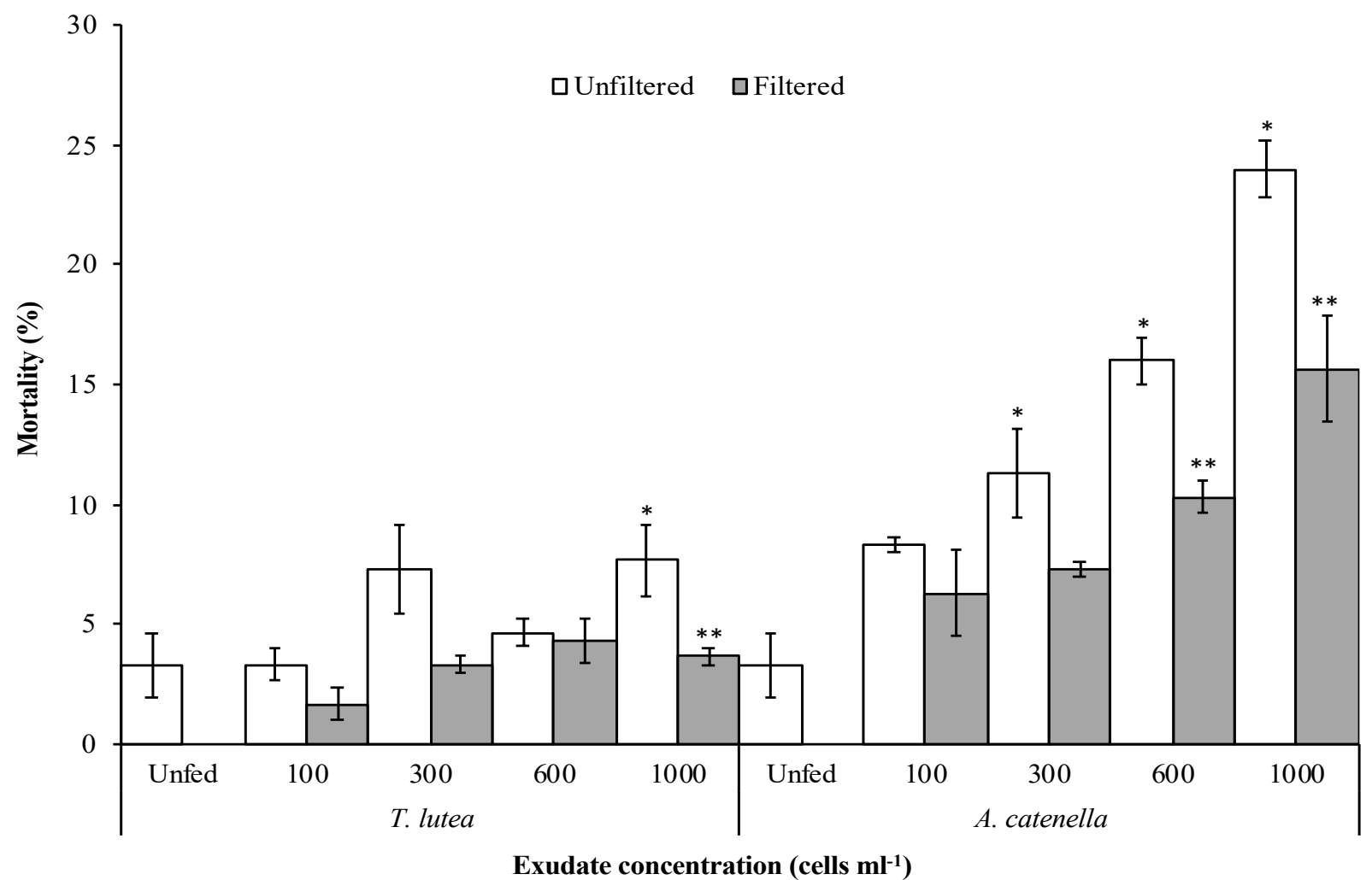

Figure 2. Mean ( $\pm \mathrm{SE}, \mathrm{n}=3$ ) mortality of oyster larvae exposed to different concentration of unfiltered and 0.22 $\mu \mathrm{m}$ filtered exudate of $A$. catenella and T. lutea. $(*)$ indicates significant difference from unfed control. (**) indicates significant difference from unfiltered exudate.

A range of studies have shown that many lethal effects, of Alexandrium species/strains, to fish and shellfish, are unrelated to the presence or production of PSTs. Instead, the lethal effects of Alexandrium include haemolytic compounds (Matsuyama, 2001; Tillman and John, 2002) or other bioactive extracellular compounds (BEC) (Borcier et al., 2017; Mardones et al., 2017; Castrec et al., 2020). 
Several studies have shown that toxic $A$. catenella have a range of sub-lethal effects on adult bivalves including mussels. Blue mussels exposed to cultures of A. catenella (Protogonyaulax tamarensis GT429) at $10^{4}$ cells $\mathrm{ml}^{-1}$ showed erratic and complete shell-valve closure, production of white, mucus-like, material and subsequent mortality of $67 \%$ of experimental animals after exposure (Shumway and Cucci, 1987). In contrast, similar studies on green mussels (Perna canaliculus) showed increased oxygen uptake but no major physiological effects or increased mortality during short-term exposure to $10^{3}$ cells $\mathrm{ml}^{-1}$ twice daily, and no mortality over a period of 2 weeks (Marsden and Shumway, 1992). These less severe effects may reflect species-level differences in response, or perhaps the lower cell concentrations/times used for the experimental exposure. Other studies of Mytilus species also demonstrated inflammatory responses, significant changes in physiological responses, hematocyte parameters, upregulation of detoxification pathways (Haberkorn et al., 2010), and immuno-compromization leading to increased parasite infection (Galimany et al., 2008). Histopathological changes have also been noted in the digestive tract (Galimany et al., 2008), similar to that observed for larvae during our exposure experiments.

\subsection{Effects of $0.22 \mu \mathrm{m}$ and activated carbon filtration on the toxicity of exudates $A$. catenella}

Larval mortality exposed to unfiltered exudates of $A$. catenella tended to increase with increasing concentration of exudates (Figure 2). Mortality was higher $(8-21 \%)$ than unfed larvae at 300, 600 and 1,000 cells $\mathrm{ml}^{-1}$, but was only significant different at the highest concentration $\left(1,000\right.$ cells $\left.\mathrm{ml}^{-1}\right)$. The $0.22 \mu \mathrm{m}$ filtration of A.catenella exudates resulted in reduced larval mortality particularly at the higher concentrations; by $6 \%$ at 600 cells ml $^{-1}$ and $8 \%$ at 1,000 cells $\mathrm{ml}^{-1}$ (Figure 2). Exposure to T. lutea filtered exudates showed similar mortality to unfed controls $(<$ $5 \%$ ) at all concentrations except 300 and 1,000 cells ml $^{-}$

${ }^{1}$ where mortality increased by $4 \%$ over the unfed controls (Figure 2). Filtration of filter-sterilized $A$. catenella exudates through granular activated-carbon reduced larval mortality by $15 \%$ compared to untreated filter-sterilized exudates (Figure 3).

The partial reduction of larval mortality by $0.22 \mu \mathrm{m}$ filtration of culture exudates of both A. catenella and $T$. lutea indicates that a proportion of the larval mortality may associate with the direct and/or indirect effects of the bacterial community associated with exudates.

Neither the mussels, oysters or cultures of $A$. catenella used in this study were axenic nor therefore might bacteria be present during experiment. However, mortality due to exposure to filter-sterilized exudates - remained higher for A. catenella than T. lutea exudates indicating that BEC produced by $A$. catenella was responsible for some of the larval mortality.

Blue mussels, oysters and culture of A. catenella used in this study were not axenic and therefore bacteria would be expected to be present during experiment. We did not characterize bacterial communities in our treatments prior to the start of the experiments and bacteria were evident during larval observation at the end of experiment. Some larvae in treatments also demonstrated internal tissue discharge and biofilms engulfing larvae, similar to that reported for bacterial infections (Sutton and Garrick, 1993).

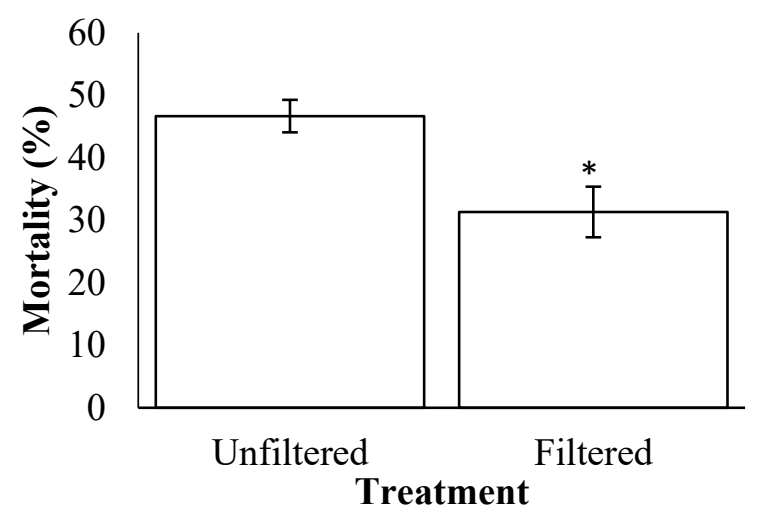

Figure 3. Mean ( $\pm \mathrm{SE}, \mathrm{n}=3$ ) mortality of blue mussel larvae exposed to unfiltered and filtered exudates of $A$. catenella through activated carbon. $(*)$ indicates significant different among treatments $(\mathrm{P}<0.05)$.

Rearing conditions for bivalve are favorable for marine bacterial growth (Brown and Tettelbach, 1988), and healthy mussel larvae cultures contain complex microbial communities, including a substantial populations of potentially pathogenic Vibrio spp. (e.g. Kwan and Bolch, 2015). For this reason, environmental or other host stress (e.g. husbandry) factors are key in the pathogenesis from commensal marine bacteria to larval bacterial pathogens. In summer exposure to and feeding of oysters with $A$. catenella to adult oysters has been shown to increase susceptibility to infection and disease due to Vibrio tasmaniensis, leading to mortalities (Abi-Khalil et al., 2016). Alternatively, susceptibility of larvae to bacterial infection may be increased indirectly by increases in dissolved organic carbon from cell exudates that in turn stimulate or alter the microbial community within the lumina (e.g. alimentary tract, over gills) of the larvae. The incidence/severity of the common shellfish hatchery disease bacillary necrosis can be increased by overfeeding, over-stocking, or the addition of various forms of dissolved organic carbon (Kwan et al., 2017). After the onset of mortality, the presence of moribund and dead larvae further accelerates infection and necrotic disease. 

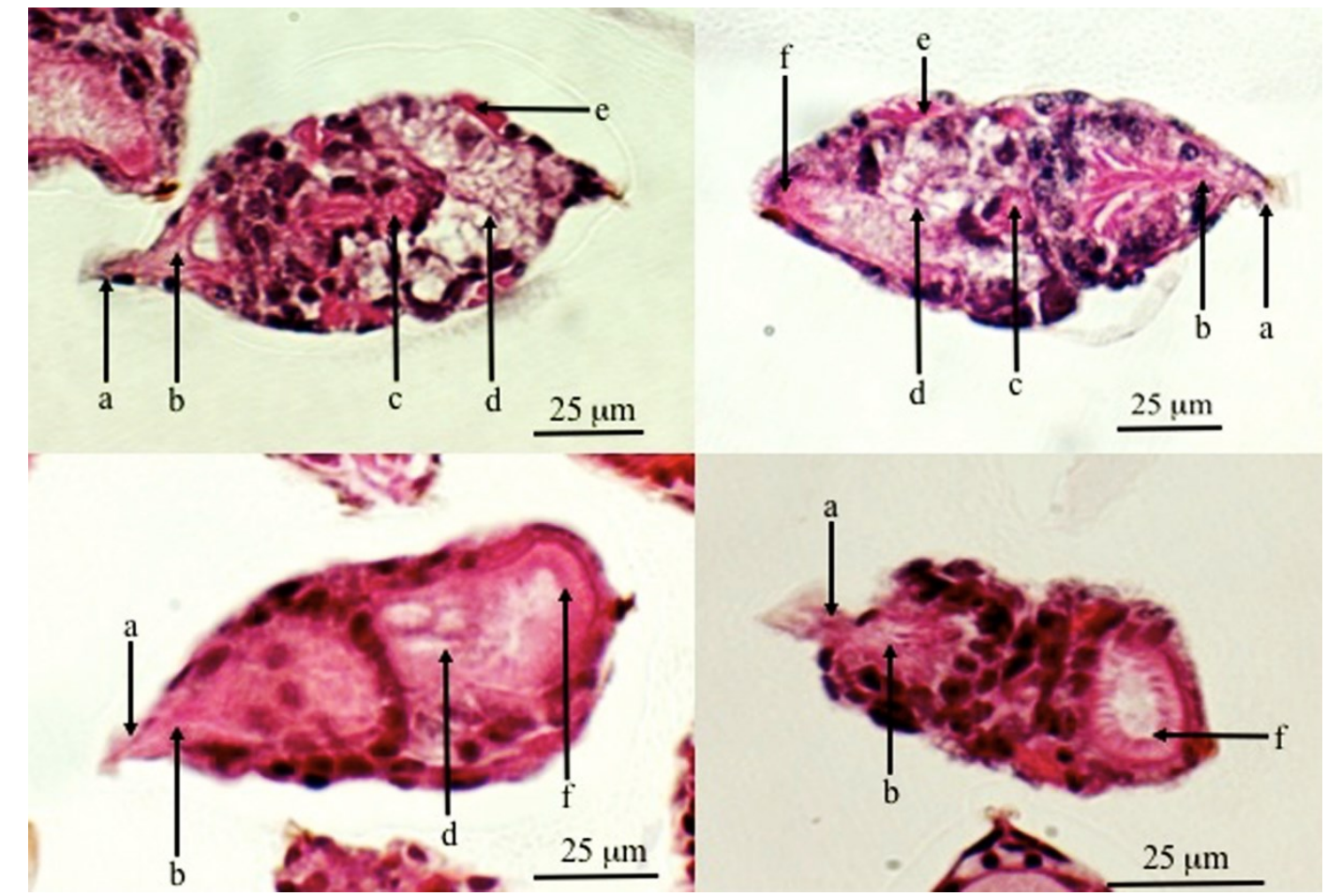

Figure 4. Structure of normal $3 \mathrm{dpf}$ blue mussel larvae showing well defined organs. a). velum of membrane, b). cilia of velum, c). esophagus, d). digestive gland, e). adductor muscle, f). style sac.

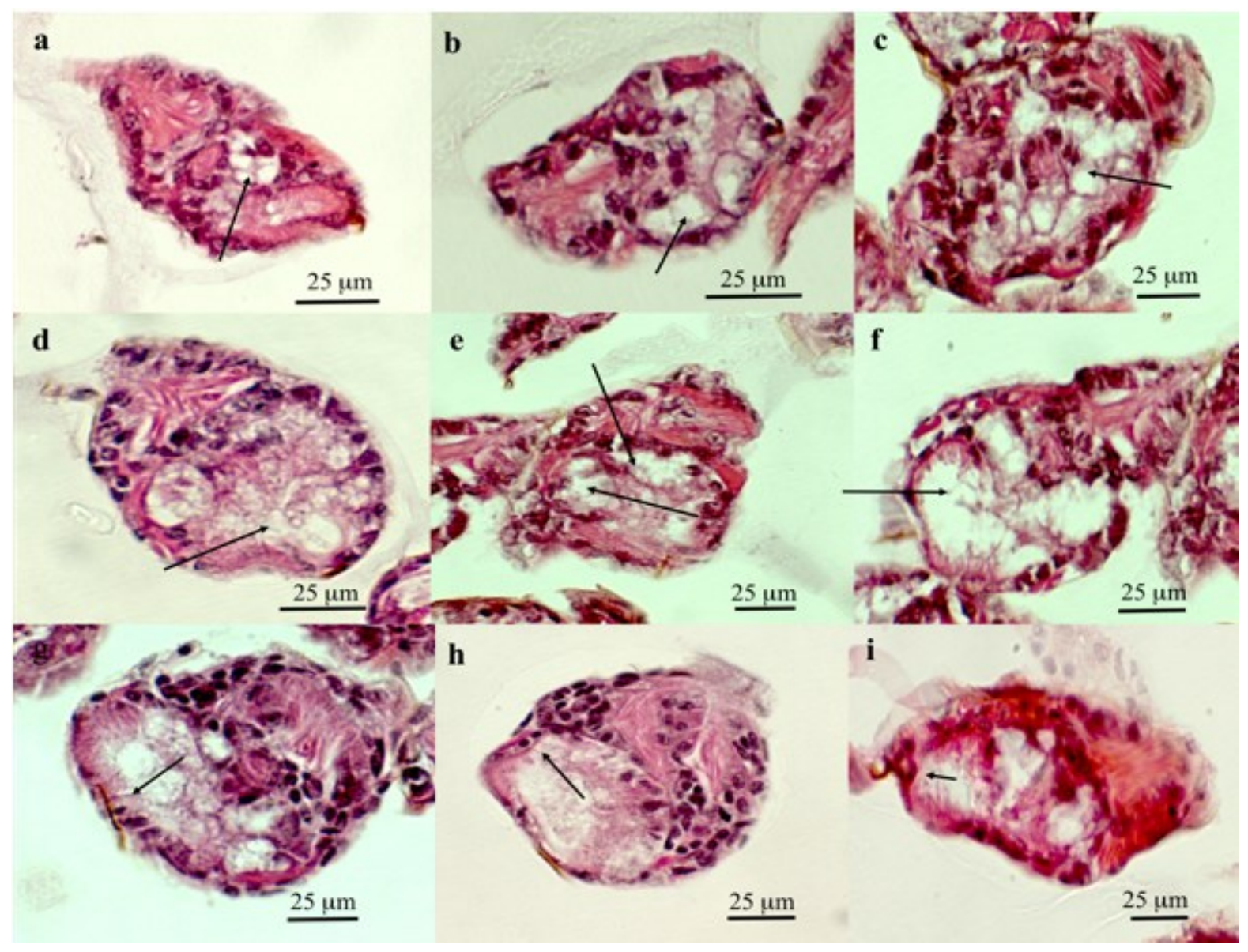

Figure 5. Structure of larvae showing the intensity of pathological changes after exposure to 1,500 cells ml-1 exudates of $A$. catenella. a-c) Intracytoplasmic vacuolation (likely degeneration) of digestive gland epithelium; mild (a) and moderate (b) after 24 hours, and heavy (c) after 48 hours. d-f). Necrosis of digestive gland epithelium; mild (d) after 3 hours, moderate (e) after 15 hours and heavy (f) after 24 hours. g-i). Cilial exfoliation from style sac epithelium; mild (g) after 15 hours, moderate (h) after 24 hours and heavy (c) after 48 hours. 

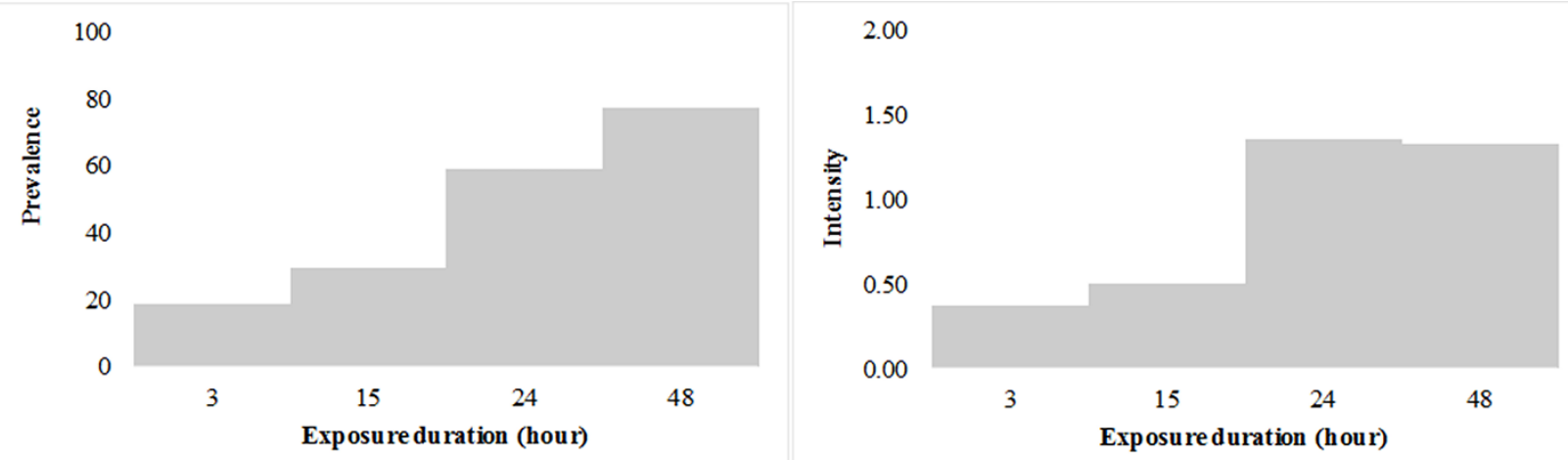

Figure 6. The prevalence and intensity of pathology in blue mussel larvae exposed to 1,500 cells ml$^{-1}$ exudates of A. catenella.
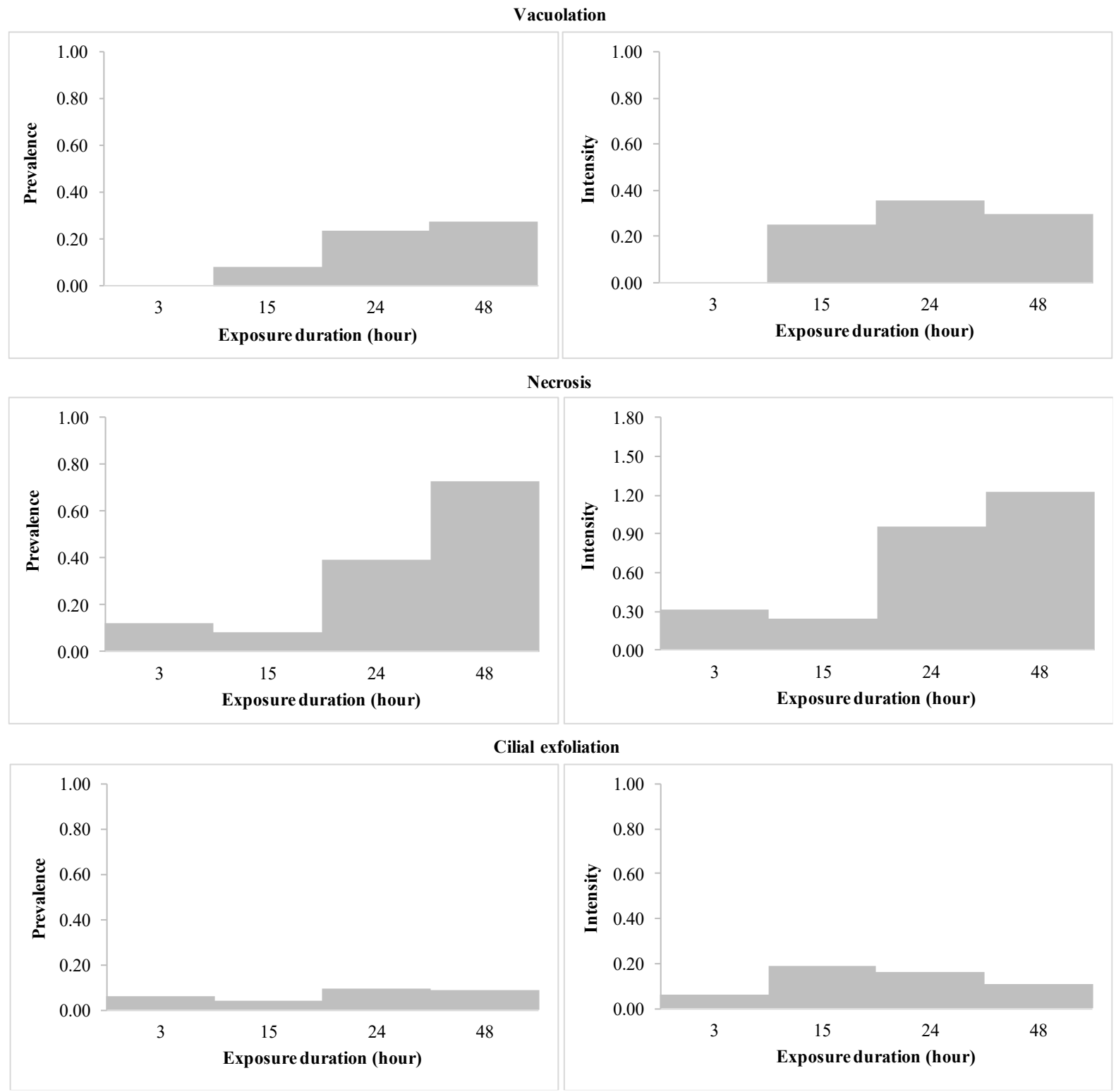

Figure 7. The prevalence and intensity of blue mussel larvae exposed to exudate of $A$. catenella over different exposure duration. 


\subsection{Histopathological effects of exudates A. catenella on blue mussel larvae}

Prior to exposure, larvae demonstrated a welldefined digestive gland and style sac with cilia on the luminal surface (Figure 4). After exposure to 1,500 cells $\mathrm{ml}^{-1}$ exudates of $A$. catenella, three pathological changes, intracytoplasmic vacuolation (likely degeneration) or hypereosinophilia with pyknotic nucleus (necrosis) of digestive gland epithelium and cilial exfoliation of style sac epithelium were observed, mainly in stomach of blue mussel larvae (Figure 5).

The histopathological changes occurred as early as 3 hours after exposure. The proportion of larvae showing histopathological changes (i.e. prevalence) and the severity of changes (i.e. intensity) was significantly different according to exposure duration $(\mathrm{p}<0.01$ for both parameters). The prevalence of larvae demonstrating histopathological changes increased from low prevalence at 3 to 15 hours exposure to intermediate at 24 to 48 hours exposure. A similar pattern was shown in the intensity of histopathological changes. The majority of larvae showed mild intensity at 3 and 15 hours exposure and this increased to moderate intensity at 24 and 48 hours exposure as shown in Figure 6.

The progression of histopathological changes was not clearly demonstrated over exposure duration that is there was no gradual increase in the numbers of necrotic epithelial cells paired with a decrease in the numbers of degenerate epithelial cells over time and with increasing dose of exposure to $A$. catenella exudate. However, the prevalence and intensity of necrosis increased with the exposure duration from low prevalence and mild intensity at 3 to 24 hours to intermediate prevalence and moderate intensity at 48 hours after exposure. In contrast, low prevalence of vacuolation and cilial exfoliation with mild intensity was evident at all duration exposure (Figure 7).

In this study, histopathological changes were mainly observed in digestive gland showing intracytoplasmic vacuolation, necrosis and cilial exfoliation of style sac. This finding was similar to previous works which reported that PSP toxins mostly accumulate in viscera causing damage of the digestive gland either through direct contact between toxic compounds and wall of digestive gland (Bricelj et al., 1990; Kwong et al., 2006; Widdows et al., 1979), or to inflammatory and immune responses of the shellfish to toxic assault (Haberkorn et al., 2010). The state of histological changes varies depending on animal stage and exposure duration. In the present study, pathological changes in digestive gland were evident as early as three hours after exposure of exudate. In contrast, pathological effects $A$. catenella on adult blue mussels were only evident after 9 days of exposure (Galimany et al., 2008).

\section{Conclusion}

The findings of this study suggest that hatchery larval mortality associated with $A$. catenella blooms is caused by a combination of extracellular toxic compounds and modification of larval culture bacterial communities due to increased/altered organic carbon from $A$. catenella. The exudate concentration equivalent to 600 cells $\mathrm{ml}^{-1}$ in this study caused the highest mortality on blue mussel larvae. The rapid histopathological changes (3 hours after exposure) and significant larval mortality observed at cell concentrations regularly observed during blooms $\left(1,500\right.$ cells $\left.\mathrm{ml}^{-1}\right)$ indicate that early detection of blooms in the vicinity of marine hatcheries in conjunction with mitigating management procedures are important to reduce severe effects of $A$. catenella blooms on shellfish larval rearing. Further studies of the nature and scale of changes in the larval microbial community and pathological change mechanism are needed to clarify the cause of larval mortality.

\section{Acknowledgment}

We would like to thank Australia Awards Scholarship for providing research funding, Spring Bay Seafood Pty Ltd, Tasmania, Australia for providing larvae and algal culture, IMAS for organizing space and instrumental set up during the experiment, Minyu for the companion during larvae collection and anonymous reviewers for their constructive comments on the manuscript.

\section{Authors' Contributions}

All authors have contributed to the final manuscript. The contribution of authors as follow, Supono designed experiment, conducted experiment, collected data and drafted manuscript. Chris Bolch and Graeme Knowles provided supervision and critical revision on the draft.

\section{Conflict of Interest}

The authors declare that there is no conflict of interest.

\section{Funding Information}

This research was funded by Australian Awards Scholarship 2015-2016.

\section{References}


Abi-Khalil, C., Lopez-Joven, C., Abadie, E., Savar, V., Amzil, Z., Laabir, M., \& Rolland, J. L. (2016). Exposure to the paralytic shellfish toxin producer Alexandrium catenella increases the susceptibility of the oyster Crassostrea gigas to pathogenic vibrios. Toxins, 8(1):24.

Anderson, D. M., Alpermann, T. J., Cembella, A. D., Collos, Y., Masseret, E., \& Montresor, M. (2012). The globally distributed Alexandrium: multifaceted roles in marine ecosystems and impacts on human health. Harmful Algae, 14:10-35.

Anderson, D. M., Hoagland, P., Kaoru, Y., \& White, A. W. (2000). Estimated annual economic impacts from harmful algal blooms (HABs) in the United States. Technical Report. National Oceanic and Atmospheric Administration Norman OK National Severe Storms Lab :97 p.

Anderson, D. M., Reguera, B., Pitcher, G. C., \& Enevoldsen, H. O. (2010). The IOC international harmful algal bloom program: history and science impacts. Oceanography, 23(4):72-85.

Basti, L., Endo, M., Segawa, S., Shumway, S. E., Tanaka, Y., \& Nagai, S. (2016). Prevalence and intensity of pathologies induced by the toxic dinoflagellate, Heterocapsa circularisquama, in the Mediterranean mussel, Mytilus galloprovincialis. Aquatic Toxicology, 163:37-50.

Bolch, C. J. S., Harwood, T., Untari, L., Murray, S., Hallegraeff, G., \& Turnbull, A. (2014, November). Alexandrium tamarense Group I as the cause of PST on the east coast of Tasmania, Australia. 14th International Conference on Harmful Algae, Wellington New Zealand.

Borcier, E., Morvezen, R., Boudry, P., Miner, P., Charrier, G., Laroche, J., \& Hegaret, H. (2017). Effects of bioactive extracellular compounds and paralytic shellfish toxins produced by Alexandrium minutum on growth and behaviour of juvenile great scallops Pecten maximus. Aquatic Toxicology, 184, 142154.

Bricelj, V. M., Lee, J. H., Cembella, A., \& Anderson, D. M. (1990). Uptake kinetics of paralytic shellfish toxins from the dinoflagellate Alexandrium catenella in the mussel Mytilus edulis. Marine Ecology Progress Series, 63:177-188

Bricelj, V. M., Lee, J. H., \& Cembella, A. D. (1991). Influence of dinoflagellate cell toxicity on uptake and loss of paralytic shellfish toxins in the northern quahog Mercenaria mercenaria. Marine Ecology Progress Series, 74:33-46.

Bricelj, V. M., Ford, S. E., Lambert, C., Barbou, A., \& Paillard, C. (2011). Effects of toxic Alexandrium tamarense on behavior, hemocyte response and de- velopment of brown ring disease in Manila clams. Marine Ecology Progress Series, 430:35-48.

Brown, C., \& Tettelbach, L. P. (1988). Characterization of nonmotile Vibrio sp. pathogenic to larvae of Mercenaria mercenaria and Crassostrea virginica. Aquaculture, 74(3):195-204.

Castrec, J., Hégaret, H., Huber, M., Le Grand, J., Huvet, A., Tallec, K., Boulais, M., Soudant, P., \& Fabioux, C. (2020). The toxic dinoflagellate Alexandrium minutum impairs the performance of oyster embryos and larvae. Harmful Algae, 92: 101744.

Cembella, A., \& John, U. (2006). Molecular physiology of toxin production and growth regulation in harmful algae. In: Granéli, E, Turner, J T (Eds.) Ecology of harmful algae (pp. 215-227). Springer.

Contreras, A. M., Marsden, I. D., \& Munro, M. H. (2012). Effects of short-term exposure to paralytic shellfish toxins on clearance rates and toxin uptake in five species of New Zealand bivalve. Marine and Freshwater Research, 63(2):166-174.

Detree C., Núñez-Acuña, G., Roberts, S., \& Gallar- doEscárate, C. (2016). Uncovering the Com- plex Transcriptome Response of Mytilus chilen- sis against Saxitoxin: Implications of Harmful Algal Blooms on Mussel Populations. PLoS One, 11(10): e0165231.

Feist, S., \& Bucke, D. (1983). A double-embedding technique for processing larval oysters for light microscopy. Bulletin of the European Association of Fish Pathologists, 1-2.

Galimany, E., Sunila, I., Hégaret, H., Ramon, M., \& Wikfors, G. H. (2008). Experimental exposure of the blue mussel (Mytilus edulis, L.) to the toxic dinoflagellate Alexandrium catenella: Histopathology, immune responses, and recovery. Harmful Algae, 7(5):702-711.

Haberkorn, H., Lambert, C., Le Goïc, N. P., Moal, J., Sequet, M., Gueguen, M., Sunila, I., \& Soudant, P. (2010). Effects of Alexandrium minutum exposure on nutrition related process and reproduc- tive output in oyster Crassostrea gigas. Harmful Algae, 9(5):427-439.

Hallegraeff, G. M. (2014). Harmful algae and their toxins: progress, paradoxes and paradigm shifts. In: G. P. Rossini (Ed.). Toxins and biologically active compounds from microalgae (pp. 4-20). CRC Press.

Hallegraeff, G. M., Bolch, C. J. S., Condie, S., DorAntes - Aranda, J. J., Murray, S., Quinlan, R., Ruvindy, R., Turnbull, A., Ugalde, S., \& Wilson, K. (2017). Unprecedented Alexandrium blooms in a previously low biotoxin risk area of Tasmania, Australia. In: Proceedings of the $17^{\text {th }}$ Internation- al Conference on Harmful Algal Blooms. Interna- 
tional Society for the Study of Harmful Algae and Intergovernmental Oceanographic Comission of UNESCO 2017.

Hégaret, H., Wikfors, G. H., \& Shumway, S. E. (2007). Diverse feeding responses of five spe- cies of bivalve mollusc when exposed to three species of harmful algae. Journal of Shell- fish Research, 26(2):549-559.

Hoagland, P., Anderson, D. M., Kaoru, Y., \& White, A. W. (2002). The economic effects of harmful algal blooms in the United States: estimates, assessment issues and information needs. Estuaries, 25(4):819-837.

Jacobson, P. J., Farris, J. L., Neves, R., \& Cherry, D. S. (1993). Use of neutral red to assess sur- vival of juvenile freshwater mussels (Bivalvia: Unionidae) in bioassays. Transactions of Amer- ican Microscopical Society, 78-80.

John, U., Litaker, R. W., Montresor, M., Murray, S., Brosnahan, M. L., \& Anderson, D. M. (2014). Formal revision of the Alexandrium tamarense species complex (Dinophyceae) taxonomy: the introduction of five species with emphasis on molecular-based (rDNA) classification. Protist, 165(6):779-804.

Kwan, T. N., \& Bolch, C. J. (2015). Genetic diversi- ty of culturable Vibrio in an Australian blue mus- sel Mytilus galloprovincialis hatchery. Disease of Aquatic Organisms, 116(1):37-46.

Kwan, T. N, Bolch, C., \& Bowman, J. (2017). Necrotic disease in bivalve larval cultures. Microbiology Australia 38, 131-133.

Kwong, R. W., Wang, W. X., Lam, P. K., \& Yu, P. K. (2006). The uptake, distribution and elimination of paralytic shellfish toxins in mussels and fish exposed to toxic dinoflagellates. Aquatic Toxicology, 80(1):82-91.

Mardones, J., Dorantes-Aranda, J. J., Nichols, P. D., \& Hallegraeff, G. M. (2015). Fish gill damage by the dinoflagellate Alexandrium catenella from Chilean fjords: Synergistic action of ROS and PUFA. Harmful Algae, 49:40-49.

Marsden, I. D., \& Shumway, S. E. (1992). Effects of the toxic dinoflagellate Alexandrium tamarense on the greenshell mussel Perna canaliculus. New Zealand Journal of Marine and Freshwater Research, 26:371-378

Matsuyama, Y. (2001). Effects of harmful algae on the early planktonic larvae of the oyster, Crassostrea gigas, Harmful Algal Blooms 2000. IOC-UNES- CO, pp. 411-414.

Mu, C., \& Li, Q. (2013). Effects of the dinoflagellate, Alexandrium catenella on the early development of the Pacific oyster Crassostrea gigas. Journal of Shellfish Research, 32(3):689694.

Munir, S., Burhan, Z. N., Nias, T., Morton, S. L., \& Siddiqui, P. J. A. (2015). Morphometric forms, biovolume and cellular carbon content of dinoflagellates from polluted waters on the Karachi coast, Pakistan. Indian Journal of Geo-Marine Science, 44(1):1925.

Núñez-Vázquez, E. J., Gárate-Lizarraga, I., BandSchmidt, C. J., Tapia, A. C., Cortes, D. J., Sandovai, F. E., Tapia, A. H., \& Guzman, J. J. (2011). Impact of harmful algal blooms on wild and cultured animals in the Gulf of California. Journal of Environmental Biology, 32(4):413-423.

Olenina, I., Hajdu, S., Edler, L., Andersson, A., Wasmund, N., Busch, S., Göbel, J., Gromisz, S., Huseby, S., Huttunen, M., Jaanus, A., Kokkonen, P., Ledaine, I., \& Niemkiewicz, E. (2006). Biovolumes and size-classes of phytoplankton in the Baltic Sea. Baltic Sea Environment Proceeding (106): 144p.

Pate, S.E., 2007. Impacts of the toxic dinoflagellate $\mathrm{Al}$ exadrium monilatum on three ecologically important shellfish species. Master Thesis. Raleigh: North Carolina StateUniversity.

Samson, J. C., Shumway, S. E., \& Weis, J. S. (2008). Effects of the toxic dinoflagellate, Alexandri- um catenella on three species of larval fish: a foodchain approach. Journal of Fish Biology, 72(1):168188.

Shumway, S. E., \& Cucci, T. L. (1987). The effects of the toxic dinoflagellate Protogonyaulax tamarensis on the feeding and behaviour of bivalve molluscs. Aquatic Toxicology, 10(1):9-27.

Sutton, D. C., \& Garrick, R. (1993). Bacterial disease of cultured giant clam Tridacna gigas larvae. Disease of Aquatic Organisms, 16(1):47-53.

Thompson, P.A., Montagnes, D. J., \& Shaw, B. A. (1994). The influence of three algal filtrates on the grazing rate of larval oysters (Crassostrea gigas), deter- mined by fluorescent microscopheres. Aquacul- ture, 119:237-247.

Tillman, U., \& Hansen, P. J. (2009). Allelopathic effects of Alexandrium tamarense on other algae: evidence from mixed growth experiments. Aquat- ic Microbial Ecology, 57(1):101-112.

Tillman, U., John, U., \& Cembella, A. (2007). On the allelochemical potency of the marine dinoflagellate Alexandrium onstenfeldii against heterotrophic and autotrophic protists. Journal of Plankton Research, 29(6):527-543.

Tillmann, U., \& John, U. (2002). Toxic effects of Alex- 
andrium spp. on heterotrophic dinoflagellates: an allelochemical defence mechanism independent of PSP-toxin content. Marine Ecology Progress Series, 230:47-58.

Trainer, V. L., \& Yoshida, T. (Ed.). (2014). Proceedings of the workshop on the economic impacts of harm- ful algal blooms on fisheries and aquaculture. PIC- ES Science Report No. 47: 85p.

Widdows, J., Moore, M., Lowe, D., \& Salkeld, P. N. (1979). Some effects of a dinoflagellate bloom (Gyrodinium aureolum) on the mussel, Mytilus edulis. Journal of the
Marine Biological Associa- tion of the United Kingdom, 59(2):522-524.

Yan, T., Zhou, M., Fu, M., Wang, Y., Yu, R., \& Li, J. (2001). Inhibition of egg hatching success and larvae survival of the scallop, Chlamys farreri, associated with exposure to cells and cell fragments of the dinoflagellate Alexandrium tamarense. Toxicon, 39(8):1239-1244.

Yan, T., Zhou, M., Fu, M., Yu, R., Wang, Y., \& Li, J. (2003). Effects of the dinoflagellate Alexandrium tamarense on early development of the scallop Argopecten irradians concentricus. Aquaculture, 217(1):167-178 